\title{
Survey of Glyphosate Residues in Honey, Corn and Soy Products
}

\section{Fernando Rubio ${ }^{*}$, Emily Guo² and Lisa kamp ${ }^{1}$}

${ }^{1}$ Abraxis, LLC, 54 Steam whistle Drive, Warminster, PA 18974, USA

${ }^{2}$ Boston University, 273 Babcock Street, Boston, MA 02446, USA

\begin{abstract}
Samples of honey (sixty nine), pancake and corn syrup (twenty six), soy sauce (twenty eight), soy milk (eleven), and tofu (twenty) purchased in the Philadelphia, US metropolitan area were analyzed for glyphosate residue using ELISA. The limit of quantification (LOQ) and range of the method were determined for honey, pancake syrup, and corn syrup to be 15 to $800 \mathrm{ppb}$; soy sauce, soy milk, and tofu 75 to $4,000 \mathrm{ppb}$. Glyphosate residues above the limit of quantification were not found in pancake and corn syrup, soy milk, and tofu. Of the sixty-nine honey samples analyzed, forty-one samples, or fifty-nine percent (59\%), had glyphosate concentrations above the method LOQ (15 ppb), with a concentration range between 17 and $163 \mathrm{ppb}$ and a mean of $64 \mathrm{ppb}$. Eleven of the tested honey samples were organic; five of the organic honey samples, or forty-five percent $(45 \%)$, contained glyphosate concentrations above the method LOQ, with a range of 26 to $93 \mathrm{ppb}$ and a mean of $50 \mathrm{ppb}$. Of the fifty-eight non-organic honey samples, thirty-six samples, or sixty-two percent $(62 \%)$, contained glyphosate concentrations above the method LOQ, with a range of 17 to $163 \mathrm{ppb}$ and a mean of $66 \mathrm{ppb}$. In addition to comparison of production method (organic vs. conventional), the honey results were evaluated according to pollen source and by country of origin, grouped by GMO usage (prohibited, limited, or permitted). Glyphosate concentrations above the method LOQ (75 ppb) were also found in ten of the twenty-eight soy sauce samples evaluated (36\%), with a concentration range between 88 and 564 ppb and a mean of $242 \mathrm{ppb}$; all organic soy sauce samples tested were below the method LOQ.
\end{abstract}

Keywords: Glyphosate; Honey; Honey bees; Soy sauce; ELISA

\section{Introduction}

Food consumption is an important pathway of human exposure to pesticides and other chemical contaminants. Studies have shown that exposure to contaminants in food could pose a public health risk $[1,2,3]$. Contaminants can enter the food supply in various ways including direct pesticide application to food crops, indirect application through the air (from drift from aerial spraying of adjacent fields), through the soil (from direct application during previous growing seasons), through the water supply (from run-off from treated areas), or through food processing (from cross-contamination from shared processing equipment) $[4,5]$.

Glyphosate (N-(phosphonomethyl) glycine) (Figure 1), commonly sold under Monsanto's trade name Roundup;, is a non-selective herbicide that inhibits 5-enolpyruvylshikimate-3-phosphate synthase (ESPS) in the shikimic acid pathway present in plants, bacteria, and archae [6]. EPSP synthase is the rate limiting step in the synthesis of various aromatic acids; inhibition of this enzyme results in depletion of aromatic amino acids such as phenylalanine, tyrosine, and tryptophan [7]. Glyphosate trans locates readily in plants, making it effective for controlling perennial weeds and overwintering rhizomes and tubers. It is registered for pre planting or postharvest treatment on crops and on non-crop land [8]. Although humans do not posses the shikimic acid pathway, we are dependent upon ingested food and gut microbes, which provide essential nutrients, which do possess this pathway. Glyphosate has been patented as an antimicrobial by Monsanto Technology LLC [9], and has been shown to disrupt gut bacteria in animals [10-12]. In humans, only a small amount $(\sim 2 \%)$ of ingested glyphosate is metabolized to amino methyl phosphonic acid (AMPA), the rest enters the blood stream and is eventually eliminated through the urine [13].

The use of glyphosate in agriculture has increased significantly with<smiles>O=C(O)CNCP(=O)(O)O</smiles>

Figure 1: Glyphosate (N-(phosphonomethyl) glycine) the introduction of transgenic crops such as Roundup-Ready soybeans and corn, which enable farmers to directly apply low cost broad spectrum herbicide products to their fields without harming crops. In the United States, glyphosate is currently the most widely used herbicide, with 180 to 185 millions pounds applied in the agricultural sector during 2007, 5 to 8 million pounds used in homes and gardens, and 13-15 million pounds used in industrial, commercial and governmental weed control applications [13]. The dramatic increase in the use of glyphosate in agriculture and landscape maintenance is occurring not only in the US, but throughout the world. This high level of use has led to concerns about its effects on humans and the environment. Glyphosate has traditionally been considered to be nearly non-toxic to humans [14], and therefore not problematic if ingested in food sources; as a consequence, measurement of its presence in food is very scarce $[15,16]$. Challenge the assertion that glyphosate is harmless, arguing that this herbicide may be a key contributor to the obesity and autism epidemics in the United States, as well as a factor in several diseases and conditions including celiac disease, Alzheimer's, Parkinson's, infertility, depression, and cancer.

Glyphosate analysis in environmental and biological matrices is problematic because of its small molecular size and structural similarity to many naturally occurring plant materials such as amino acids and secondary plant compounds. It is highly soluble in water, thereby making its extraction with solvents difficult and matrix effects highly prevalent. As a result, glyphosate isolation and quantification has posed a challenge to the analytical chemist. Numerous analytical procedures have been published in the literature for the detection of this highly

*Corresponding author: Abraxis, LLC, 54 Steam whistle Drive, Warminster PA 18974, USA, Tel: (215) 357-3911; FAX: (215) 357-5232; E-mail: frubio@ abraxiskits.com

Received October 02, 2014; Accepted November 13, 2014; Published November 19,2014

Citation: Rubio F, Guo E, Kamp L (2014) Survey of Glyphosate Residues in Honey, Corn and Soy Products. J Environ Anal Toxicol 4: 249. doi: 10.4172/2161 0525.1000249

Copyright: $\odot 2014$ Rubio F, et al.. This is an open-access article distributed under the terms of the Creative Commons Attribution License, which permits unrestricted use, distribution, and reproduction in any medium, provided the original author and source are credited. 
polar and amphoteric molecule [17], including gas chromatography (GC), high performance liquid chromatography (HPLC) and capillary electrophoresis (CE), often coupled with mass spectrometry (MS). The co-contaminants in environmental and biological matrixes render instrumental analysis costly and time-consuming. ELISA determination, however, has allowed for the rapid, selective and sensitive determination of glyphosate [18-24].

The main objective of this survey was to obtain representative data on levels of glyphosate residues in honey, corn and pancake syrup, and soy based products, such as soy sauce, soy milk, and tofu, in products consumed by the general population in and around Philadelphia, Pennsylvania. The analytical program included the extraction of glyphosate from the various matrices and the subsequent determination of glyphosate residues by enzyme linked immune sorbent assay (ELISA).

\section{Materials and Methods}

\section{Chemicals and reagents}

Chemicals were of reagent grade and were purchased from Sigma Chemical Company, St. Louis MO, USA, except as indicated. Glyphosate ( $>98 \%$ purity), Chem Service, West Chester, PA, USA. Glyphosate micro titer plate ELISA, Abraxis PN 500086; Glyphosate sample diluent, PN 500082, Abraxis LLC, Warminster, PA, USA. Glyphosate stock solution was prepared in deionized water to $1.0 \mathrm{mg} /$ $\mathrm{mL}$; spiking solutions were prepared from the working solution using deionized water.

\section{Samples and sample preparation/extraction}

In total, 153 representative samples were purchased from markets in the Philadelphia metropolitan area (69 honey, 26 corn and pancake syrup, 28 soy sauce, 11 soy milk, and 20 tofu products).

Honey, corn and pancake syrup samples: A $0.50 \mathrm{~g}$ aliquot of sample was weighed into a micro centrifuge tube and $0.50 \mathrm{~mL}$ of $1 \mathrm{~N}$ $\mathrm{HCl}$ was added. The sample was mixed for 2 minutes using a vortex mixer, then diluted by adding $40 \mu \mathrm{L}$ of the acid treated sample into $3.96 \mathrm{~mL}$ of glyphosate sample diluent and mixed using a vortex mixer. The sample was then analyzed in the ELISA. The sample preparation/ extraction described above produced a 1:200 sample dilution.

Soy sauce: A $0.10 \mathrm{~mL}$ aliquot of sample was transferred into a micro centrifuge tube and $0.90 \mathrm{~mL}$ of $1 \mathrm{~N} \mathrm{HCl}$ was added. The sample was mixed for 2 minutes using a vortex mixer, then diluted by adding 40 $\mu \mathrm{L}$ of the acid treated sample into $3.96 \mathrm{~mL}$ of glyphosate sample diluent and mixed using a vortex mixer. The sample was then analyzed in the ELISA. The sample preparation/extraction described above produced a 1:1000 sample dilution.

Soy milk: A $0.10 \mathrm{~mL}$ aliquot of sample was transferred into a micro centrifuge tube and $0.90 \mathrm{~mL}$ of $1 \mathrm{~N} \mathrm{HCl}$ was added. The sample was mixed for 2 minutes using a vortex mixer, and then centrifuged at 6,000 $\mathrm{x} g$ for 5 minutes. The sample was then diluted by adding $40 \mu \mathrm{L}$ of the middle layer of the acid treated sample into $3.96 \mathrm{~mL}$ of glyphosate sample diluent and mixed using a vortex mixer. The sample was then analyzed in the ELISA. The sample preparation/extraction described above produced a 1:1000 sample dilution.

Tofu: A $1.0 \mathrm{~g}$ aliquot of sample was weighed into a $20 \mathrm{~mL}$ vial and $10.0 \mathrm{~mL}$ of $1 \mathrm{~N} \mathrm{HCl}$ was added. The sample was mixed for 2 minutes using a vortex mixer, and then allowed to separate for 2 minutes. Approximately $1 \mathrm{~mL}$ of the mixture was transferred into a micro centrifuge tube and centrifuged at $6,000 \mathrm{x}$ g for 5 minutes. The sample was then diluted by adding $40 \mu \mathrm{L}$ of the middle layer of the acid treated sample into $3.96 \mathrm{~mL}$ of glyphosate sample diluent and mixed using a vortex mixer. The sample was then analyzed in the ELISA. The sample preparation/extraction described above produced a 1:1000 sample dilution.

\section{Determination of glyphosate in samples}

The instructions provided in the ELISA kit user's guide were followed, in brief, glyphosate calibrators provided in the kit and the samples to be tested are derivatized for ten minutes and then added, along with an antibody specific for glyphosate to micro titer wells coated with goat anti-rabbit antibody and incubated for thirty minutes with shaking. A glyphosate horseradish peroxidase (HRP) enzyme conjugate is then added. At this point a competitive reaction occurs between the glyphosate, in the calibrators or samples, and the enzyme labeled glyphosate for the antibody binding sites on the micro titer well. The reaction is allowed to continue for sixty minutes. After a washing step an enzyme substrate (hydrogen peroxide) and the chromogen (3,3',5,5'-tetramethylbenzidine) are added. The enzyme-labeled glyphosate bound to the glyphosate antibody catalyzes the conversion of the substrate /chromogen mixture to a colored product. After an incubation period, the reaction is stopped and stabilized by the addition of diluted acid and read in a Molecular Devices micro titer plate reader (450 $\mathrm{nm}$ ). Since the labeled glyphosate (conjugate) was in competition with the unlabeled glyphosate (sample) for the antibody sites, the color developed is inversely proportional to the concentration of glyphosate in the sample.

\section{Data analysis}

The evaluation of the assay was performed using Molecular Devices Soft max pro evaluation program (4-Parameter). The program calculates the mean absorbance value for each of the standards $\left(\mathrm{B}_{\mathrm{i}}\right)$ and calculates the $\% \mathrm{~B}_{\mathrm{i}} / \mathrm{B}_{0}$ for each standard by dividing the mean absorbance value for each standard by the Zero Standard (Standard 0) mean absorbance $\left(\mathrm{B}_{0}\right)$. The program then constructs a non-linear regression model of a standard curve by plotting the $\% \mathrm{~B}_{\mathrm{i}} / \mathrm{B}_{0}$ for each standard on the vertical linear (y) axis versus the corresponding glyphosate concentration on the horizontal logarithmic ( $\mathrm{x}$ ) axis. The $\% \mathrm{~B}_{\mathrm{i}} / \mathrm{B}_{0}$ for samples is interpolated using the standard curve yielding sample concentration levels of glyphosate from the standard curve. Correlation coefficients of the assays were $>0.995$ and standard deviation between standard replicate analysis were $<10 \%$.

\section{Validation, performance and quality control}

Specificity had been previously determined (ELISA user's guide), (Table 1). Recovery, limit of quantitation, range and limit of quantification were determined to test the validity of the dilution/ extraction procedures of each of the matrices used in combination with the glyphosate ELISA.

\begin{tabular}{|c|c|c|}
\hline COMPOUND (B/Bo) & LOD $(\mathbf{n g} / \mathbf{m L})$ & $\mathbf{5 0} \% \mathbf{B} / \mathbf{B o}(\mathbf{n g} / \mathbf{m L})$ \\
\hline Glyphosate & 0.05 & 0.5 \\
\hline Glyphosine & 50 & 3,000 \\
\hline Glufosinate & 2,000 & 70,000 \\
\hline AMPA & 35,000 & $>1,000,000$ \\
\hline Glycine & $>10,000$ & $>1,000,000$ \\
\hline
\end{tabular}

Table 1: Cross-rectivity table. The reactivity of glyphosate to various related compounds expressed as LOD and as the dose required for $50 \%$ absorbance inhibition (50\% B/Bo). 
Citation: Rubio F, Guo E, Kamp L (2014) Survey of Glyphosate Residues in Honey, Corn and Soy Products. J Environ Anal Toxicol 4: 249. doi: $10.4172 / 2161-0525.1000249$

Page 3 of 8

\section{Results and Discussion}

The method performance for glyphosate analysis was determined by conducting recovery tests on each of the matrices. To determine the accuracy of the glyphosate analysis for the sample matrices analyzed in this study, matrix samples that were glyphosate negative and positive (positive samples were not encountered with tofu, soy milk, pancake and corn syrup) were spiked as follows: 15, 40, 100, 200 and $400 \mathrm{ng} /$ $\mathrm{mL}$ (honey, pancake and corn syrup); 75, 200, 500, 1,000 and 4,000 $\mathrm{ng} / \mathrm{mL}$ [soy sauce, soy milk and tofu (ng/g)]. Analysis was performed in duplicate for all unspiked and spiked samples at all levels. Average recovery obtained for glyphosate negative honey samples fortified with glyphosate was $119 \%$, $(\mathrm{SD}=10)$. Average recovery for glyphosate positive honey (unspiked contained $44 \mathrm{ng} / \mathrm{g}$ glyphosate) after fortification was $116 \%(\mathrm{SD}=10)$. Average recovery for negative soy sauce was $94 \%(\mathrm{SD}=5)$, and for positive fortified soy sauce (unspiked contained $417 \mathrm{ng} / \mathrm{mL})$ was $86 \%(\mathrm{SD}=5)$. The limit of quantification and range of the method were determined for honey, pancake and corn syrup to be 15 to $800 \mathrm{ng} / \mathrm{g}$; soy sauce, soy milk, and tofu 75 to $4,000 \mathrm{ng} /$ $\mathrm{mL}$ or $\mathrm{ng} / \mathrm{g}$, respectively.

In this study, the first sample matrix analyzed for the presence of glyphosate was honey; 69 samples were analyzed and classified into 18 groups depending on the country of origin listed on the bottles: (A) Brazil, (B) Canada, (C) China, (D) Germany, (E) Greece, (F) Hungary, (G) India, (H) Korea, (I) blend of Mexico, Brazil, and Uruguay, (J) New Zealand, (K) Spain, (L) Taiwan, (M) blend of Ukraine and Vietnam, (N) USA, (O) blend of USA and Argentina, (P) blend of USA, Argentina and Canada, (Q) blend of USA, South America, (R) unknown origin. The glyphosate concentrations obtained are shown in (Figure 2). Fortyone out of the sixty-nine honey samples analyzed, or fifty nine percent
(59\%), had glyphosate concentrations above the method LOQ (15 $\mathrm{ng} / \mathrm{g}$ ) with a concentration range between 17 and $163 \mathrm{ng} / \mathrm{g}$ and a mean of $64 \mathrm{ng} / \mathrm{g}$.

The glyphosate concentration in honey grouped by flower (pollen) source is shown in (Figure 3). The pollen types listed on the bottles were: clover (12 samples), exotic (11 samples), wildflower (11 samples), unknown (35 samples). (Figure 4) depicts the concentration of glyphosate in honey samples grouped by growing method of source pollen: organic (11 samples) and traditional (58 samples); 5 of the 11 organic samples had glyphosate concentrations above the method LOQ with a range of 26 to $93 \mathrm{ng} / \mathrm{g}$ and a mean of $50 \mathrm{ng} / \mathrm{g}$. Of the fifty-eight non-organic honey samples, thirty-six samples, or sixty-two percent (62\%), contained glyphosate concentrations above the method LOQ, with a range of 17 to $163 \mathrm{ppb}$ and a mean of $66 \mathrm{ppb}$.

(Figure 5) depicts the concentration of glyphosate in honey by country and whether the use of genetically modified organisms (GMO) seeds is prohibited or permitted. The graph also shows where some minimum uses of GMO traits are allowed (Spain, and blend of Vietnam/Ukraine). The glyphosate concentration in honey originating in countries that do not allow or allow limited GMO traits (3 out of 14 samples above the LOQ) ranged from 26 to $41 \mathrm{ng} / \mathrm{g}$ with a mean of 31 $\mathrm{ng} / \mathrm{g}$. The glyphosate range for those countries that allow GMO (30 out of 43 samples above LOQ) was 21 to $163 \mathrm{ng} / \mathrm{g}$ with a mean of $71 \mathrm{ng} / \mathrm{g}$. Samples of unknown origin ( 8 out of 12 samples above LOQ) ranged from 17 to $95 \mathrm{ng} / \mathrm{g}$ with a mean of $50 \mathrm{ng} / \mathrm{g}$.

The second matrix group analyzed for glyphosate was soy sauce. The analysis consisted of 28 samples, (Figure 6). Ten out of 28 samples (36 \%) had glyphosate concentrations above the method LOQ (75 ng/

\section{Glyphosate in Honey}

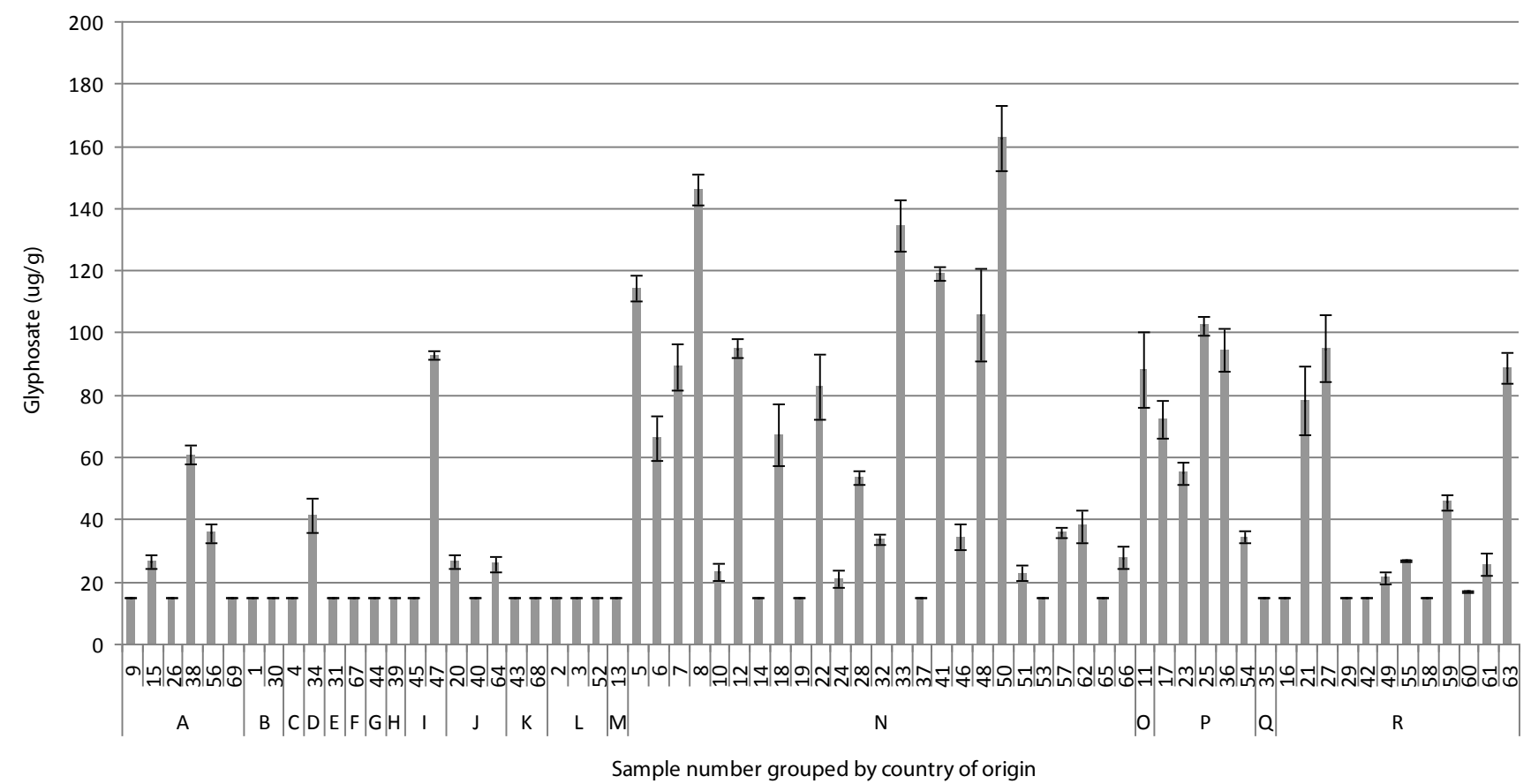

Figure 2: Concentration of glyphosate (ng/g) in honey samples listed by honey origin: (A) Brazil, (B) Canada, (C) China, (D) Germany, (E) Greece, (F) Hungary, (G) India, (H) Korea, (I) blend of Mexico, Brazil, and Uruguay, (J) New Zealand, (K) Spain, (L) Taiwan, (M) blend of Ukraine and Vietnam, (N) USA, (O) blend of USA and Argentina, (P) blend of USA, Argentina and Canada, $(Q)$ blend of USA, South America, (R) unknown origin. Dashed line represents LOQ of method $(15 \mathrm{ng} / \mathrm{g})$. Error bars represent concentrations obtained during duplicate analysis. 
Citation: Rubio F, Guo E, Kamp L (2014) Survey of Glyphosate Residues in Honey, Corn and Soy Products. J Environ Anal Toxicol 4: 249. doi: 10.4172/2161-0525.1000249

Page 4 of 8

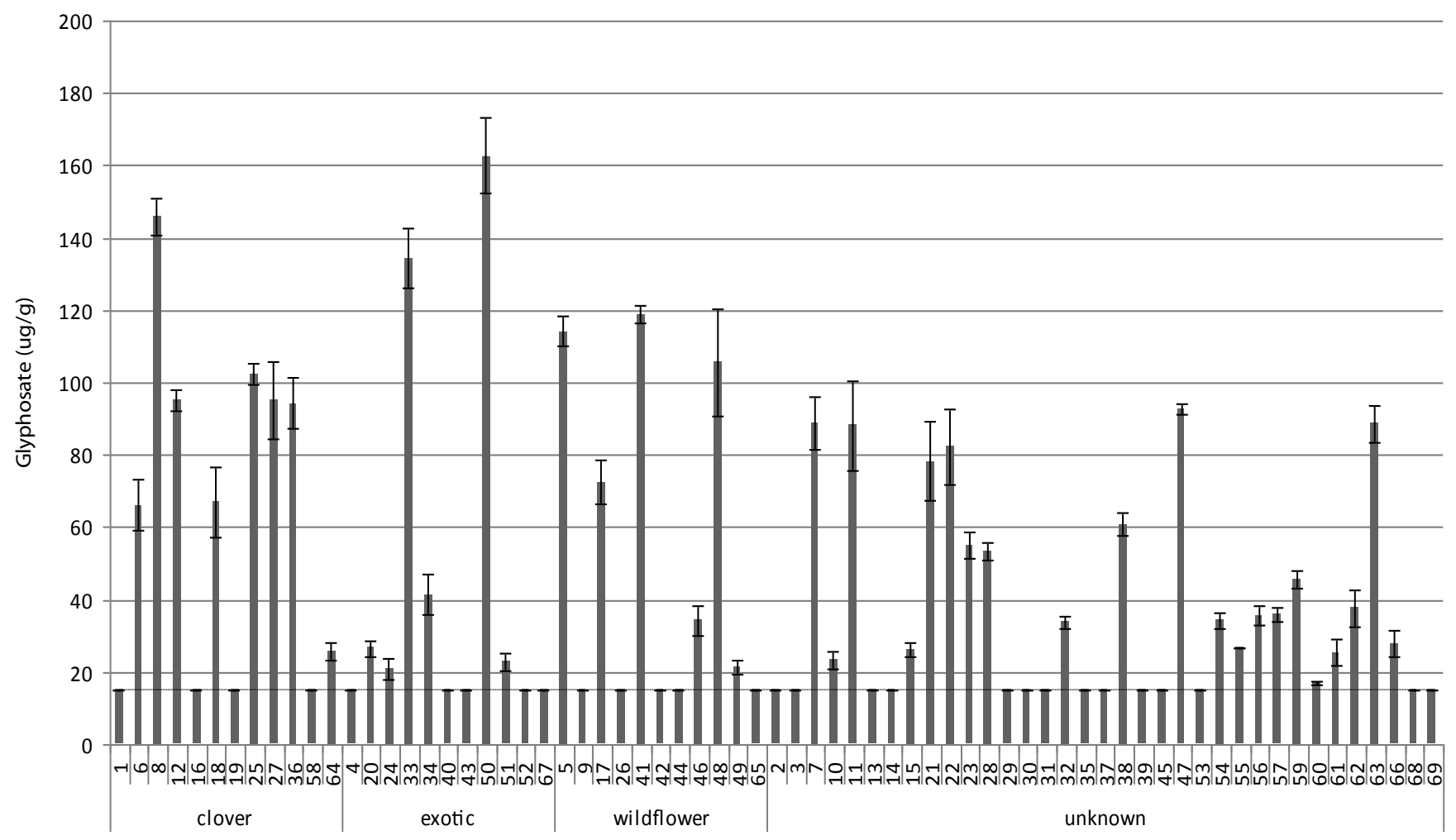

Sample number, grouped by pollen source

Figure 3: Concentration of glyphosate $(\mathrm{ng} / \mathrm{g})$ in honey samples by flower (pollen) source. Dashed line represents LOQ of method (15 $\mathrm{ng} / \mathrm{g})$. Exotic flowers were sophora, manuka, orange, cactus, summer flower, lychee, alfalfa, acacia.). Error bars represent concentrations obtained during duplicate analysis.

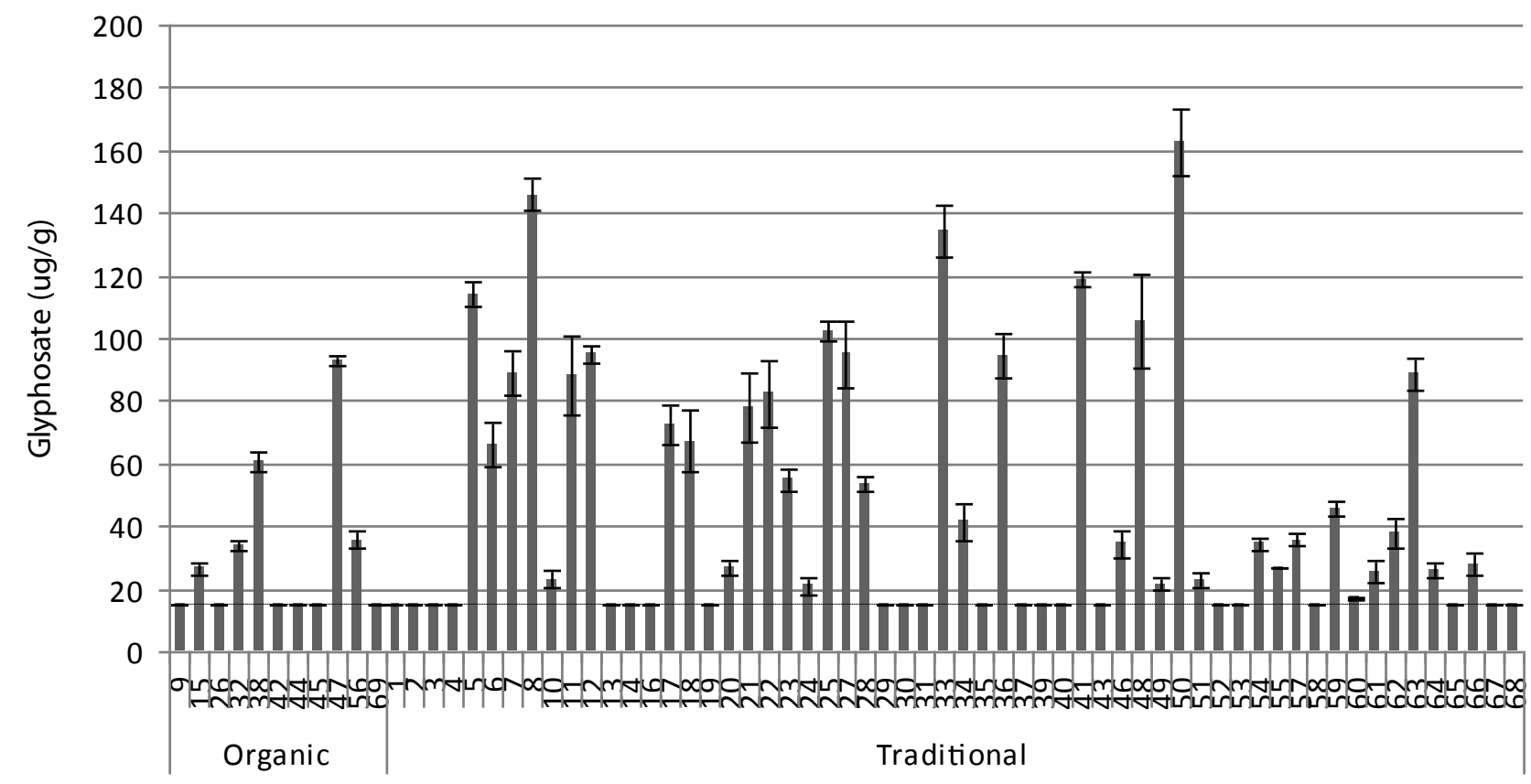

Sample numbers, grouped by growing method of source pollen

Figure 4: Concentration of glyphosate (ng/g) in honey samples by growing method of source pollen (Organic vs. Traditional). Dashed line represents LOQ of method $(15 \mathrm{ng} / \mathrm{g})$.) Error bars represent concentrations obtained during duplicate analysis. 
Citation: Rubio F, Guo E, Kamp L (2014) Survey of Glyphosate Residues in Honey, Corn and Soy Products. J Environ Anal Toxicol 4: 249. doi: $10.4172 / 2161-0525.1000249$

Page 5 of 8

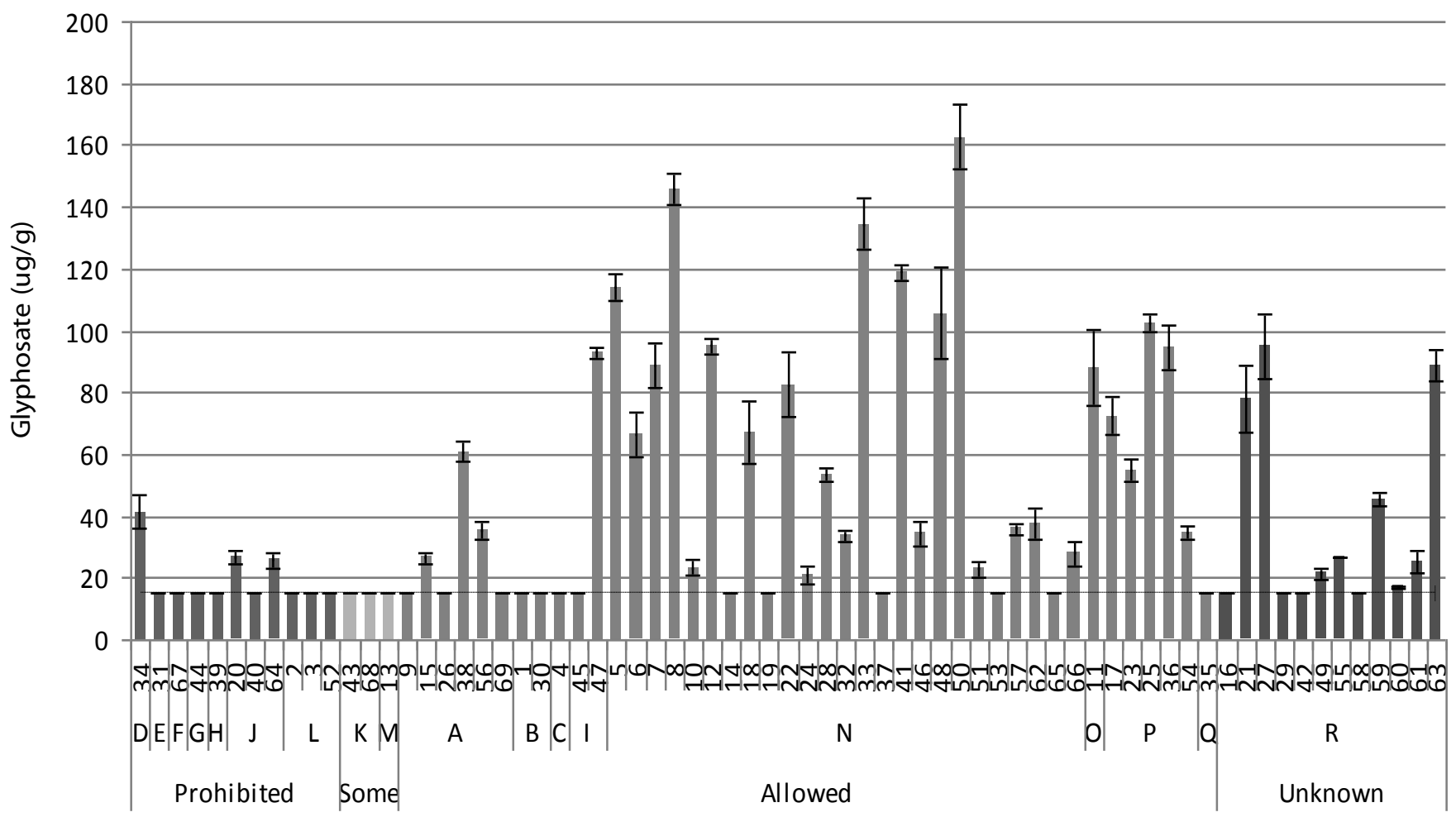

Sample numbers, grouped by country of origin and use of GMO foods

Figure 5: Concentration of glyphosate (ng/g) in honey samples listed by honey origin and the allowance of GMO use: (A) Brazil, (B) Canada, (C) China, (D) Germany, (E) Greece, (F) Hungary, (G) India, (H) Korea, (I) blend of Mexico, Brazil, and Uruguay, (J) New Zealand, (K) Spain, (L) Taiwan, (M) blend of Ukraine and Vietnam, (N) USA, (O) blend of USA and Argentina, (P) blend of USA, Argentina and Canada, $(\mathrm{Q})$ blend of USA, South America, $(\mathrm{R})$ unknown origin. Dashed line represents LOQ of method $(15 \mathrm{ng} / \mathrm{g})$. ). Error bars represent concentrations obtained during duplicate analysis.

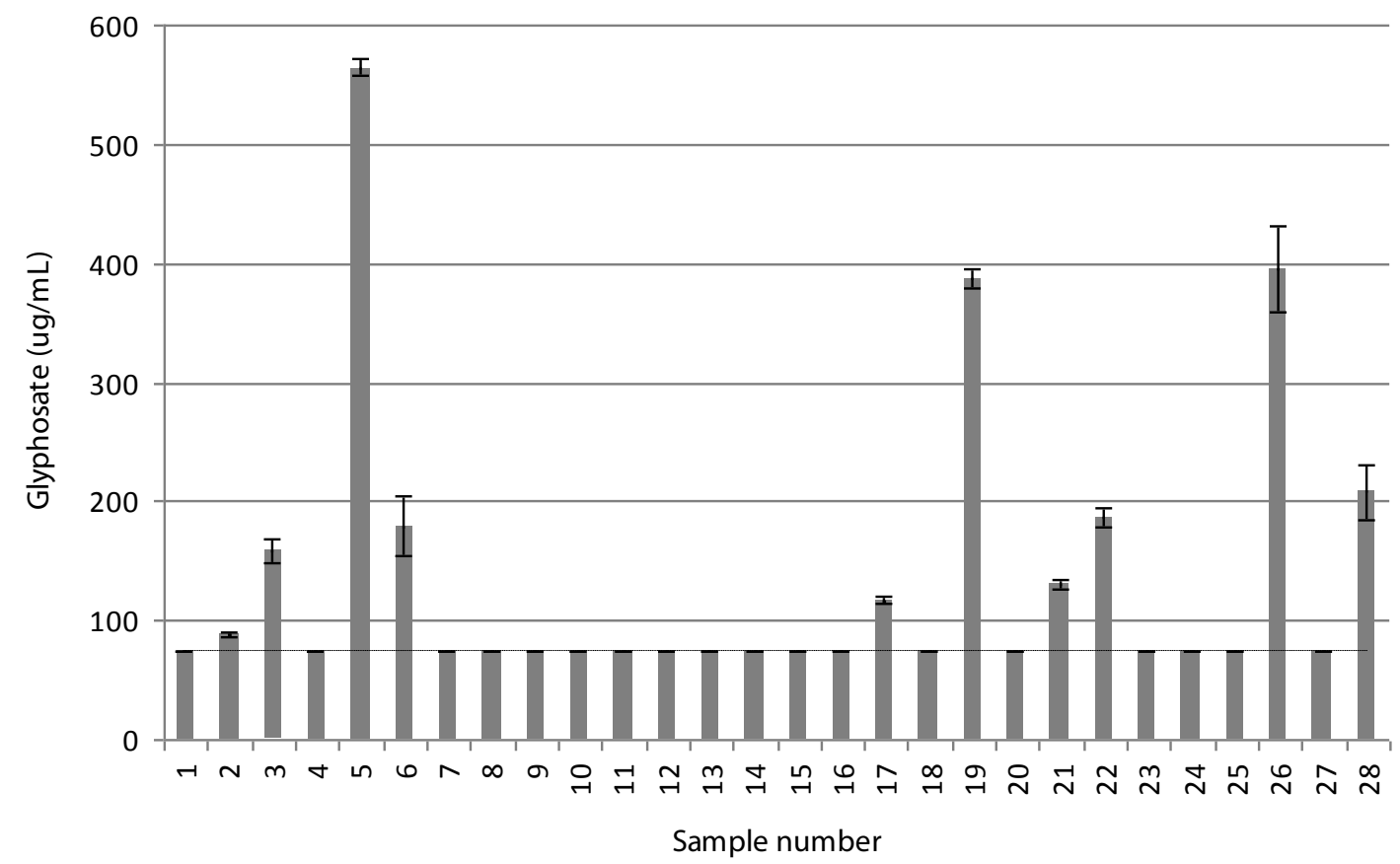

Figure 6: Concentration of glyphosate $(\mathrm{ng} / \mathrm{mL})$ in soy sauce samples. Dashed line represents LOQ of $\mathrm{method}(75 \mathrm{ng} / \mathrm{mL})$.). Error bars represent concentrations obtained during duplicate analysis. 
$\mathrm{mL}$ ) with a concentration range between 88 and $564 \mathrm{ng} / \mathrm{mL}$ and a mean of $242 \mathrm{ng} / \mathrm{mL}$. (Figure 7) shows the concentration of glyphosate in soy sauce by method of soy bean growing (organic vs. traditional). The recent report from the Chinese Academy of Medical Science and the Beijing Union Hospital [20] reported an average glyphosate concentration in soy sauce of $133 \mathrm{ng} / \mathrm{mL}$ in samples that did not specify on the bottle whether or not the raw material was GM soybean. In our study, the small subset of organic labeled samples (three) was all below the limit of quantitation of the test.

Corn and pancake syrup (26 samples), soy milk (11 samples), and tofu (20 samples) tested were negative for glyphosate at the LOQ of the method (15 ng/g for pancake and corn syrup, and $75 \mathrm{ng} / \mathrm{mL}$ or $\mathrm{ng} / \mathrm{g}$ for soy milk and tofu, respectively).

Studies on glyphosate residues in food are scarce. Among the few studies found was a recent report published on the incidence of glyphosate in soy sauce, conducted by the Chinese government [20]. Searches were conducted by the authors using various scientific databases on the concentration and incidence of glyphosate in honey, but these failed to provide any information. The honey samples analyzed in the present study show that $59 \%$ of all samples contained glyphosate residues (ranging from 17 to $163 \mathrm{ng} / \mathrm{g}$, mean $64 \mathrm{ng} / \mathrm{g}$ ); the residue concentration does not seem to depend on pollen source or growing method, even organic honey contained glyphosate residues ( 5 out 11 samples, or $45 \%$, mean glyphosate concentration $50 \mathrm{ng} / \mathrm{g}$ ). Comparing the concentration of glyphosate in honey by countries that use GMO extensively with countries that allow the use of some GMO traits and those that do not allow GMO, shows that, in general, glyphosate levels are lower in samples from countries that do not allow or allow limited use of some GMO traits, such as Spain and Vietnam/ Ukraine blend (mean $31 \mathrm{ng} / \mathrm{g}$ ), compared to those countries that allow planting of GMO traits $(71 \mathrm{ng} / \mathrm{g})$. It should be noted, however, that some residues of glyphosate (although $<50 \mathrm{ng} / \mathrm{g}$ ) were found in honeys originating from Germany and New Zealand, countries where no GMO planting is allowed.

The European Union has specific guidelines for the labeling of organic honey $[25,26]$. According to those guidelines, the location of apiaries is strictly controlled and states that "Nectar and pollen sources available over a three-kilometer radius around the apiary sites must consist essentially of organically produced crops or crops treated with low-environmental-impact methods. Apiaries must also be far enough away from any non-agricultural production source that could lead to contamination (e.g. urban centers, waste dumps, waste incinerators, etc.). Member States have the option of prohibiting the production of organic honey in certain regions or areas that do not meet these conditions. Organic honey must not contain chemicals residues (synthetic pesticides, etc.)." The United States has no such guidelines for the organic production of honey, but uses organic farming certification for honey labeling purposes; one reason is that it is practically impossible to regulate without testing all honey for residues since bees can fly up to 3 miles in search of nectar and it is difficult to be certain that they do not feed on nectar contaminated by crop spraying or industrial sources. In the EU, glyphosate residues in non-organic honey regulatory limits are $50 \mathrm{ng} / \mathrm{g}$ [27], the United States does not have a limit in honey. The limit in drinking water in the United States is $700 \mathrm{ng} / \mathrm{mL}$; the reference dose is $1.75 \mathrm{mg} / \mathrm{Kg} /$ day; the One-Day Health Advisory level is $20 \mathrm{mg} / \mathrm{L}$ [28]. Also, it is widely known that like milk and olive oil, honey is one of the foods that is most commonly mislabeled and adulterated [29] providing yet another source of glyphosate contamination in honeys that, according to the bottle label, originated in non-GMO countries.

Bee colony collapse disorder (CCD) is a growing threat to the efficient production of food around the world. Honey bees pollinate nearly 130 species of plant life [30], such as fruits, vegetables, nuts, and seed crops. Honeybees are therefore indirectly responsible for an

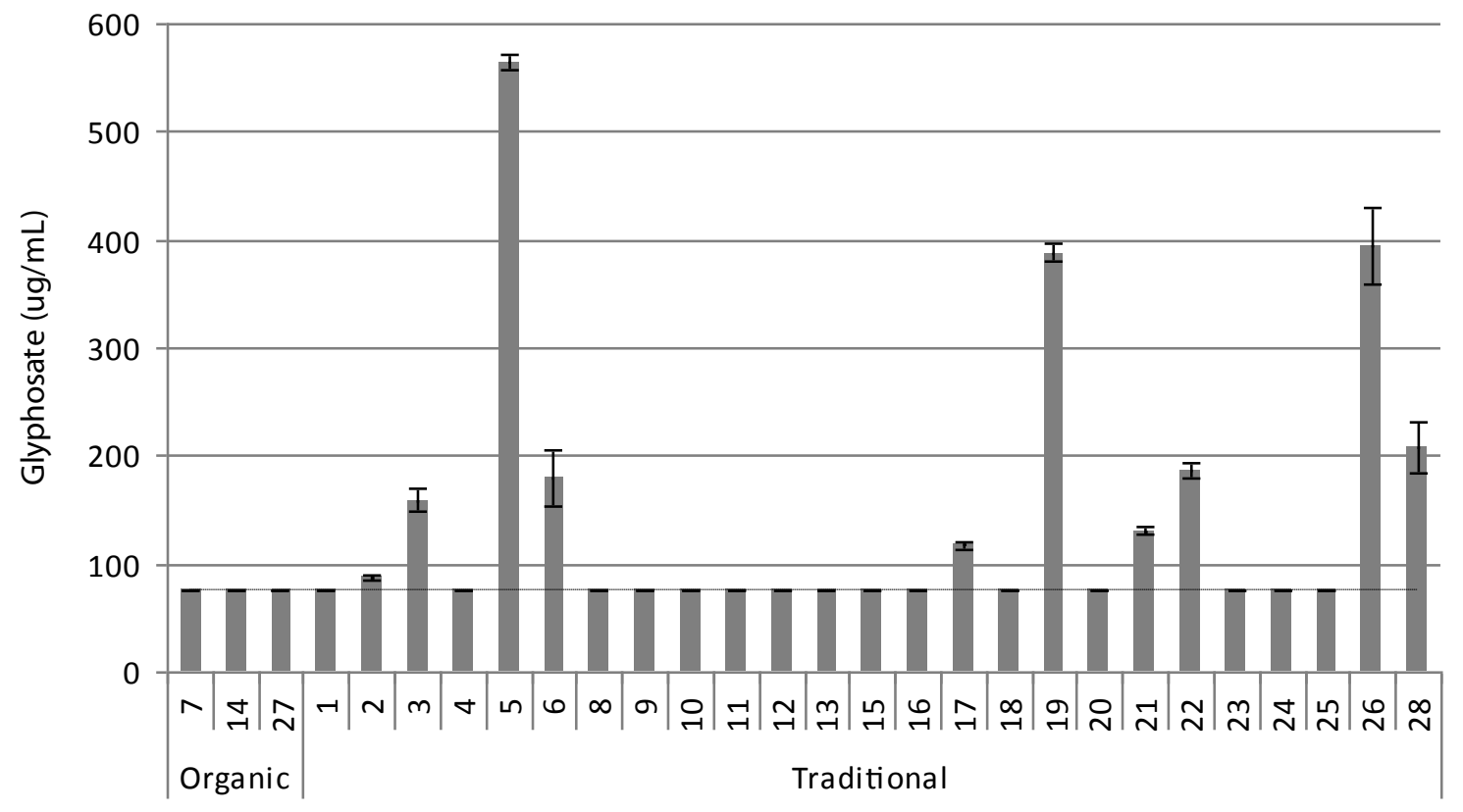

Sample numbers, grouped by soy growing method

Figure 7: Concentration of glyphosate $(\mathrm{ng} / \mathrm{mL})$ in soy sauce samples by growing method of soy beans (Organic vs. Traditional). Dashed line represents $\mathrm{LOQ}$ of method $(75 \mathrm{ng} / \mathrm{mL})$. ). Error bars represent concentrations obtained during duplicate analysis. 
estimated one-third of the world food supply [31]. Although several factors are involved in CCD, including numerous pathogens and parasites, the extensive use of pesticides [32,33] such as neonicotinoids have provided evidence that these products are harmful to honey bees and have lead to a recent ban or restriction in the use of three neonicotoids by the European Union [34]. Although glyphosate is not acutely toxic to bees, it is chronically toxic to animals and is reported to disrupt the endocrine system $[35,36]$ and a recent study indicates that honey bees exposed to increasing sub-lethal concentrations of glyphosate exhibit a decrease in acetyl cholinesterase (AChE) activity [37]. The high rate of glyphosate use creates the potential for wide-spread contamination of our food chain. Glyphosate is used throughout the bee foraging period in high amounts and is found in the air, water, and in plant parts frequented by bees, such as flowers and buds, potentially contaminating the nectar collected by bees from contaminated plants [38]. Based on its prevalence in the environment, as well as our findings in honey samples, we propose that future studies should be conducted to determine if glyphosate is in fact a contributing factor in CCD.

\section{Conclusion}

This study indicates the presence of glyphosate residues in honey and soy sauce, but not in pancake and corn syrups or soy based products such as soy milk and tofu. Forty one out of sixty nine (59\%) honey samples analyzed contained glyphosate at a concentration above the method LOQ $(15 \mathrm{ng} / \mathrm{g})$ with a range between $17-163 \mathrm{ng} / \mathrm{g}$ and a mean of $64 \mathrm{ng} / \mathrm{g}$. Ten out of twenty eight (36\%) soy sauce samples contained glyphosate at a concentration above the method LOQ $(75 \mathrm{ng} / \mathrm{mL})$ with a range between $88-564 \mathrm{ng} / \mathrm{mL}$ and a mean of $242 \mathrm{ng} / \mathrm{mL}$. Future studies should be conducted on many other food products to determine the extent of glyphosate residue contamination.

\section{Acknowledgements}

We would like to give our thanks to Erin Faltin for the preparation of the graphs presented in this paper.

\section{References}

1. Maitani T (2004) Evaluation of exposure to chemical substances through foodsExposure to pesticides, heavy metals, dioxins, acrylamide and food additives in Japan. J Health Sci 50: 205-209.

2. National Research Council (1993) Pesticides in the Diets of Infants and Children. Natl. Acad Sci -Natl Res. Council, Washington, DC.

3. Wiles R, Davies K, Campbell C (1998) overexposed: Organophosphate Insecticides in Children's Food. Environmental Working Group, Washington, DC.

4. Battaglin WA, Meyer MT, Kuivila KM, Dietze JE (2014) Glyphosate and its degradation product AMPA occur frequently and widely in U.S. soils, surface water, groundwater, and precipitation. JAWRA 50: 275-289.

5. Damals CA, Eleftherohorinos IG (2011) Pesticide Expousre, Safety Issues, and Risk Assessment Indicators. Int J Environ Res Public Health 8: 1402-1419.

6. De Maria N, Becerril JM, Garca-Plazaola JI, Hernandez AH, de Felipe MR, et al. (2006) New insights on glyphosate mode of action in nodular metabolism: Role of shikimate accumulation. J Agric Food Chem 54: 2621-2628.

7. Duke SO, Powles SB (2008) Glyphosate: A once-in-a-century herbicide. Pest Manag Sci 64: 319-325.

8. Vencill, WK (2002) Weed Science Society of America, Lawrence, KS. Herbicide Handbook, $8^{\text {th }}$ ed 231-234.

9. Monsanto Technology LLC (2010) Glyphosate formulations and their use for the inhibition of 5-enolpyruvylshikimate-3-phosphate synthase.

10. Shehata AA, Schrodi W, Aldin AA, Hafez HM, Kruger M (2013) The effect of glyphosate on potential pathogens and beneficial members of poultry microbiota in vitro. Curr Microbiol 66: 350-358.
11. Kruger M, Shehata AA, Schrodl W, Rodloff A (2013) Glyphosate suppresses the antagonistic effects of Enterococcus spp. On Clostridium botulinum Anaerobe 20: 74-78

12. Carman JA, Vlieger HR, Ver Steeg LJ, Sneller VE, Robinson GW, et al. (2013) A long term toxicology study on pigs fed a combined genetically modified (GM) soy and GM maize diet. J Organic Syst. 8: 38-54.

13. United States EPA (2007) Pesticide Market Estimates Agriculture Home and Garden Last accessed July 13, 2014

14. Williams GM, Kroes R, Munro IC (2000) Safety evaluation and risk assessment of the herbicide Roundup and its active ingredient, glyphosate, for humans. Regul Toxicol Pharmacol $31: 117-165$.

15. Samsel A, Seneff S (2013) Glyphosate, pathways to modern diseases II: Celiac sprue and gluten intolerance. Inter discip Toxico. 6: 159-184.

16. Samsel A, Seneff S (2013) Glyphosate's Supression of Cytochrome P450 Enzymes and Amino Acid Biosynthesis by the Gut Microbiome: Pathways to Modern Diseases. Entropy 15: 1416-1463.

17. Stalikas CD, Konidari CN, (2001) Analytical methods to determine phosphonic and amino acid group-containing pesticides. J Chromatogr A 907: 1-19.

18. Kruger MP, Schledorn W, Schrodl A, Hoppe HW, Lutz W, et al. (2014) Detection of Glyphosate Residues in Animals and Humans. J Environ Anal Toxicol 4 100210.

19. Kruger M, Schrodl W, Neuhaus AJ, Shehata AA (2013) Field Investigations of Glyphosate in Urine of Danish Cows. J Environ Anal Toxicol 3: 100086.

20. Mortl M, Nemeth G, Juracsek J, Darvas B, Kamp L, et al. (2013) Determination of glyphosate residues in Hungarian water samples by immunoassay. Micro chemical Journal 107: 143-151.

21. Sanchis J, Kantiani L, Llorca M, Rubio F, Ginebreda A, et al. (2012) Anal Bioanal Chem 402: 2335-2345.

22. Bernal MH, Solomon KR, Carrasquilla G (2009) Toxicity of formulated glyphosate (glyphos) and cosmo-flux to larval and juvenile Colombian frogs 2. Field and laboratory microcosm acute toxicity. J Toxicol Environ Health $A$ 72: $966-973$

23. Byer JD, Stuger J, Klawunn P, Todd A, Sverko E (2008) Low Cost Monitoring of Glyphosate in Surface Waters Using the ELISA Method: An Evaluation. Environ Sci Technol 42: 6052-6057.

24. Rubio F, Veldhuis L, Clegg BS, Fleeker JR, Hall JC (2003) Comparison of a Direct ELISA and HPLC Method for Glyphosate Determination in Water. J Agric Food Chem 51: 691-696.

25. European Commission (1999) Council Regulation (EC) No 1804/1999 of 19 July 1999 supplementing Council Regulation No. 2092/91 on organic production of agricultural products and indications thereto on agricultural products and foodstuffs.

26. European Commission (1991) Council Regulation (EC) No 2092/91 of 24 June 1991 on organic production of agricultural products and indications thereto on agricultural products and foodstuffs

27. European Commission (2013) Council Regulation (EC) No 293/2013 of 20 March 2013 Ammending Annexes II and III to Regulation EC No 396/2005 of the European Parliament and of the Council as regards maximum residue levels of emanectin benzoate, etofenprox, etoxazole, flutriafol, glyphosate, phosmet, pyraclostrobin, spinosad and spirotetramat in or on certain products.

28. United States EPA. 2009. Glyphosate. Human-Health Assessment Scoping Document in Support of Registration Review. U.S. Environmental Protection Agency, Office of Prevention, Pesticides, and Toxic Substances, Office of Pesticide Programs, U.S. Government Printing Office: Washington, DC.

29. Strayer SE, Everstine K, Kennedy S (2014) Economically Motivated Adulteration of Honey: Quality Control Vulnerabilities in the International Honey Market. Food Protection Trends 34: 8-14.

30. Kaplan JK (2008) A Complex Buzz. Agricultural Research 56.5: 8-11.

31. Delaplane KS, Mayer DF (2001) Crop Pollination by Bees. Entomologia Experimentalis et Applicata 99: 127-129.

32. Johnson RM, Ellis MD, Mullin CA, Frazier M (2010) Pesticides and honey bee toxicity. Apidologie 41: 312-332.

33. Wu JY, Anelli CM, Shepard WS (2011) Sub-lethal effects of pesticide residues 
Citation: Rubio F, Guo E, Kamp L (2014) Survey of Glyphosate Residues in Honey, Corn and Soy Products. J Environ Anal Toxicol 4: 249. doi: 10.4172/2161-0525.1000249

Page 8 of 8

in brood comb on worker honey bee (Apis mellifera) development and longetivity. PLOS ONE 6: e14720.

34. European Commission (2013) Council Regulation (EC) No 485/2013 of 24 May 2013 Amending Implementing Regulation (EU) No 540/2011, as regards the conditions of approval of the active substances clothianin, thiamethoxam and imidacloprip, and prohibiting the use and sale of seeds treated with plant protection products containing those active substances.

35. Antoniou M, Habib MEM, Howard CV, Jennings RC, Leifert C, et al. (2012) Terato genic Effects of Glyphosate-Based Herbicides: Divergence of Regulatory Decisions from Scientific Evidence. J Environ Anal Toxicol S4 :006.
36. Gassnier C, Dumont C, Benachour N, Clair E, Chagnon MC, et al. (2009) Glyphosate-based herbicides are toxic and endocrine disruptors in human cell lines. Toxicology 262: 184-191.

37. Boily M, Sarrasin B, DeBlois C, Ara P, Chagnon M (2013) Acetylcholinesterase in Honey bees (Apis mellifera) exposed to neonicotinoids, atrazine and glyphosate: laboratory and filed experiments. Environ Sci Pollut Res 20: 56035614.

38. China Food Economy (2014) Agricultural Chemical Residuals Have Been Detected in Food Products Processed from Imported GM Soybeans by the China Food Economy Website revealed. 